Note

\title{
Comprehensive Analysis of an Antarctic Bacterial Community with the Adaptability of Growth at Higher Temperatures than those in Antarctica
}

\author{
SHOKO HOSOI-TANABE ${ }^{1 *}$, HONGYAN ZHANG ${ }^{1}$, DAOCHEN ZHU', \\ SHINICHI NAGATA ${ }^{1}$, SYUHEI BAN ${ }^{2}$, AND SATOSHI IMURA ${ }^{3}$ \\ Research Center for Inland Seas, Kobe University, 5-1-1 Fukaeminami, \\ Higashinada, Kobe 658-0022, Japan \\ ${ }^{2}$ The University of Shiga Prefecture, 2500 Hassaka-cho, \\ Hikone-City, Shiga 522-8533, Japan \\ ${ }^{3}$ National Institute of Polar Research, 10-3 Midoricho, Tachikawa, Tokyo 190-8518, Japan \\ Received 3 September, 2009/Accepted 13 January, 2010
}

\begin{abstract}
To investigate the adaptability to higher temperatures of Antarctic microorganisms persisting in low temperature conditions for a long time, Antarctic lake samples were incubated in several selection media at $25^{\circ} \mathrm{C}$ and $30^{\circ} \mathrm{C}$. The microorganisms did not grow at $30^{\circ} \mathrm{C}$; however, some of them grew at $25^{\circ} \mathrm{C}$, indicating that the bacteria in Antarctic have the ability to grow at a wide range of temperatures. Total DNA was extracted from these microorganisms and amplified using the bacteria-universal primers. The amplified fragments were cloned, and randomly selected 48 clones were sequenced. The sequenced clones showed high similarity to the $\alpha$-subdivision of the Proteobacteria with specific affinity to the genus Agrobacterium, Caulobacter and Brevundimonas, the $\beta$-subdivision of Proteobacteria with specific affinity to the genus Cupriavidus, and Bacillus of the phylum Firmicutes. These results showed the presence of universal genera, suggesting that the bacteria in the Antarctic lake were not specific to this environment.
\end{abstract}

Key words : Antarctic lake/Bacterial community/16S rRNA gene/Temperature-adaptability.

Antarctica is one of the most extreme environments on the earth, and low temperatures and nutrient deficiency affect the diversity of organisms in the Antarctic biotope. This environment is characterized by its geographical isolation, and most parts of the continent have had little or no anthropogenic influence for a long time (Ellis-Evans, 1996). Therefore, Antarctic microorganisms including bacteria and fungi, which have persisted in low temperature environments for long periods, are believed to be peculiar and adapted to this extreme environment. However, accompanying researchers who have entered Antarctica in the last few decades, there is a possibil-

*Corresponding author. Tel \& Fax: +81-78-431-6354 E-mail:syonatsu(a)maritime.kobe-u.ac.jp ity that the Antarctic ecosystem includes not only the native organisms adapted to the Antarctic environment at low temperatures but also the organisms that have invaded this continent. On the other hand, when researchers go back to their countries, several microorganisms, which are peculiar to Antarctica, might accompany them and affect the ecosystem in the new habitat. However, it has not been clarified in detail whether there are microorganisms with the adaptability both to low and high temperatures, and whether some microorganisms can grow only under a low or high temperature environment.

In Antarctica, a large number of lakes harbor pristine biotopes that are subject to long periods of ice and snow cover, and low temperatures (LaybournParry and Marchant, 1992; Laybourn-Parry et al., 
1997). Also around Japan's Syowa Station, there are lakes of various sizes, water temperatures, and $\mathrm{pH}$, and a large ecosystem peculiar to Antarctica. Microorganisms adapted to the Antarctic environment also might inhabit these lakes and play several important roles in the hydrosphere ecosystem. However, there is little knowledge about the microorganisms in these lakes, and their diversity and adaptability to various environments have not been clarified. Considering the increase of the movement of microorganisms between Antarctica and other continents accompanying people traveling to and from these places, it is important to know comprehensively the characteristics of Antarctic microorganisms, and to consider the possibility that the microorganisms from Antarctica might be introduced into the warmer regions. In this study, we cultivated Antarctic lake samples at higher temperatures than found in their normal habitat, and investigated the adaptability of these organisms to higher temperatures.

Samples were collected from Jizo-lke (Fig.1B, no.8), an Antarctica lake, on December 30, 2003 at
Skavrvsnes (Fig.1A-b, B) in the Syowa Station (Fig.1A-a) area by the Japanese Antarctic Research Expedition (JARE)-45. Samples were stored at -20 ${ }^{\circ} \mathrm{C}$ until the experiment. The water temperature at this site was $6.8^{\circ} \mathrm{C}$, and $\mathrm{pH}$ was 7.83 .

The collected samples were added to LB medium $(2.5 \% \mathrm{v} / \mathrm{v})$ or, albumin medium $(2.5 \% \mathrm{v} / \mathrm{v})$, which were developed for bacterial growth (Sato, 1987; McEvoy, 2006) or to YM medium (2.5\% v/v), which was developed for yeast growth and acid-tolerant microorganisms (Peng et al., 1999). Since the sampling site was an oligotrophic lake and a low nutrient concentration medium might stimulate the growth of the microorganisms, 100-fold LB medium was used. These media were incubated aerobically at a rotation speed of $120 \mathrm{rpm}$ at $25^{\circ} \mathrm{C}$ and $30^{\circ} \mathrm{C}$. Growth was determined by measuring the optical density at $600 \mathrm{~nm}$ $\left(O D_{600}\right)$ using a spectrophotometer (DU 640, Beckman, Fullerton, CA, U.S.A.).

As a result, while growth was not observed in YM medium for $10 \mathrm{~d}$ at $30^{\circ} \mathrm{C}$, the microorganisms grew at $25^{\circ} \mathrm{C}$, and the cell turbidity approached the maximum

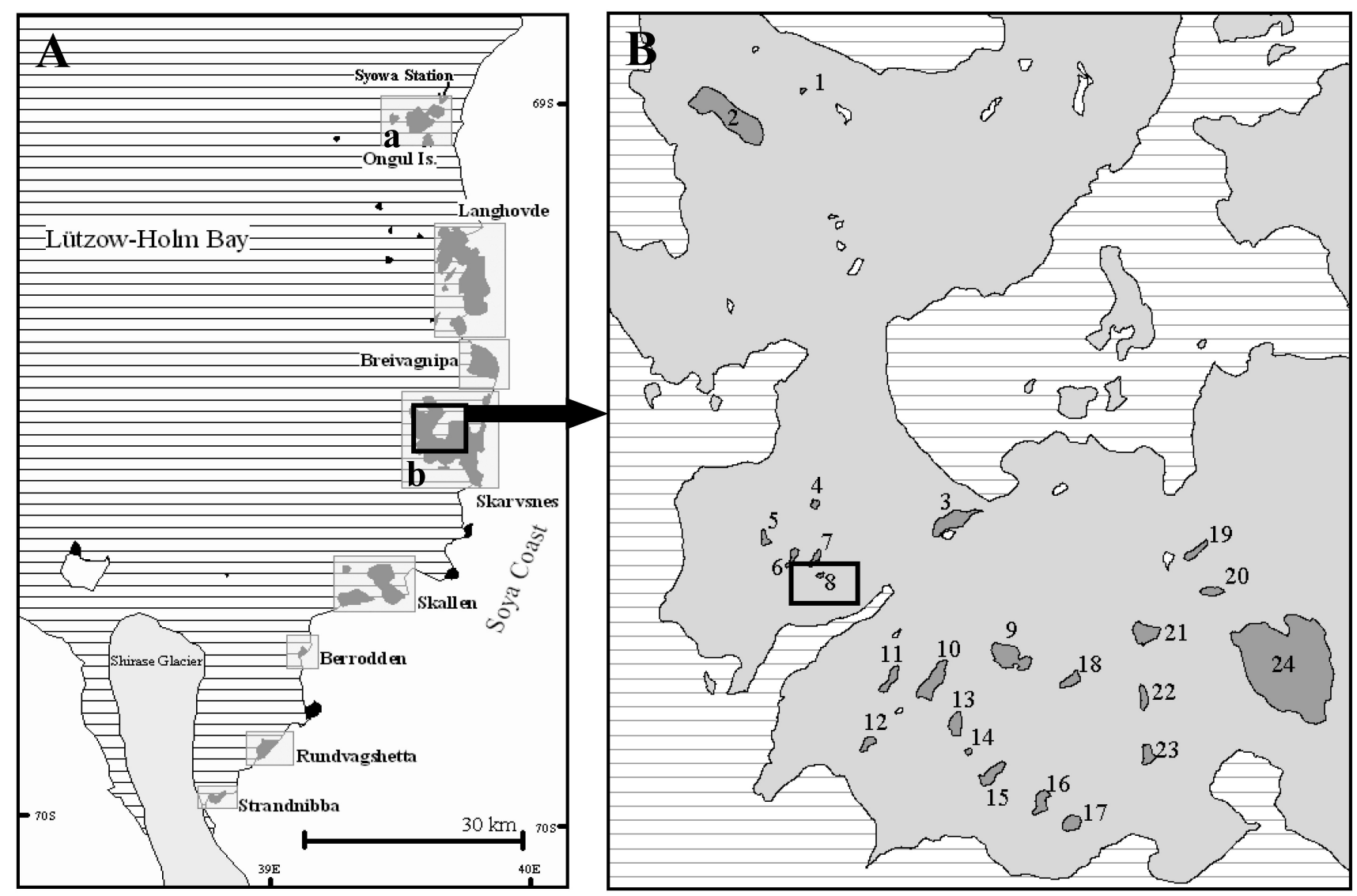

FIG. 1. The location of sampling site. The sample was collected from Jizo-lke in the Skarvsunes region near the Japanese Antarctic Station (Syowa Station). A, Syowa Station area (a, Syowa Station; b, Skarvsnes region). The square shows the enlarged area in B; B, Enlarged map of the Skarvsnes region. no.8, Jizo-lke. 
after cultivation at $100 \mathrm{~h}$ (data not shown). The cells did not grow in the albumin medium after $10 \mathrm{~d}$ either at $25^{\circ} \mathrm{C}$ or $30^{\circ} \mathrm{C}$ (data not shown). Although the growth of cells was not observed in the 100-fold diluted LB medium after $10 \mathrm{~d}$ at $30^{\circ} \mathrm{C}$, growth was detected in the diluted $\mathrm{LB}$ at $25^{\circ} \mathrm{C}$, and the cell turbidity approached the maximum $\mathrm{OD}_{600}(0.1)$ at $9 \mathrm{~d}$ (data not shown).

The results of culturing showed that some bacteria did not have the ability to grow at a high incubation temperature $\left(30^{\circ} \mathrm{C}\right)$ but could grow at $25^{\circ} \mathrm{C}$. The samples had been collected from the lake at $6.8^{\circ} \mathrm{C}$, and bacteria in habiting this environment was thought to be adapted to this low temperature and able to grow only at low temperatures. However, this adaptation did not restrict the growth temperature. Some bacteria might survive at a wide range of temperatures, and be similar to bacteria in this environment physiologically and taxonomically.

Until now, some bacteria able to grow at a lower temperature have been recognized as "psychrophiles" and "psychrotrophs" (Bowman et al., 2000; Brambilla et al., 2001). A psychrophile is defined as an organism that is capable of growing at or below $0{ }^{\circ} \mathrm{C}$, but unable to grow above $20^{\circ} \mathrm{C}$. On the other hand, a psychrotroph can grow well above 20 ${ }^{\circ} \mathrm{C}$ and has the capability to grow at $0{ }^{\circ} \mathrm{C}$. Psychrophiles and psychrotrophs are widely distributed in nature, with $80 \%$ of the biosphere having temperatures below $5{ }^{\circ} \mathrm{C}$. In this study, the selected bacteria from the Antarctic lake could grow at temperatures higher than that of the lake $\left(25^{\circ} \mathrm{C}\right)$, suggesting that they are psychrotrophs with the ability to grow at lower temperatures, and survive at a wide range of temperatures.

The concentration of the carbon source in the used three media was higher than that of the Antarctic lake. Especially, its concentration in the YM medium was the highest among the media examined. However, the most active growth of bacteria was observed in YM medium, showing that bacteria in the Antarctic lake with low photosynthetically active radiation (Laybourn-Parry and Marchan, 1992; Laybourn-Parry et al., 1997) have the ability to also grow in the medium containing abundant nutrients. A lot of bacteria in the environment containing low amount of nutrients were considered as "oligotrophic bacteria", which do not grow easily and actively in the medium used in laboratory (Ohta and Hattori, 1983; Suwa and Hattori, 1984). While the bacteria in the Antarctic lakes might be thought to be oligotrophic with their adaptation to low level of nutrients, the results in this study indicated that the range of nutrient concentration for the active growth was wide, and the bacteria in the Antarctic lakes might be distributed widely in other environments and grow universally at a global level.

After culturing, genomic DNA was extracted from the bacteria growing in 100-fold diluted LB medium and YM medium, sequenced and analyzed phylogenetically. First, cells in $1,000 \mathrm{ml}$ culture were pelleted by centrifugation at $10,000 \times \mathrm{g}$ for $10 \mathrm{~min}$ at $4{ }^{\circ} \mathrm{C}$. DNA was extracted and purified using the Wizard $^{\circledR}$ Genomic DNA Purification Kit (Promega, Madison, USA). The extracted genomic DNA was subjected to PCR using the bacterial universal primer set, EUB27F: 5'-AGAGTTTGATCMTGGCTCAG-3' and EUB1492R: 5'-TACGGYTACCTTGTTACGACTT$3^{\prime}$, targeting small subunit ribosomal rRNA gene (rDNA). The PCR was performed in $20 \mu \mathrm{l}$ volumes containing 0.025 units/ $\mu$ I of Takara Ex Taq (Takara Bio Co. Ltd, Shiga, Japan), $1 \times$ Ex Taq Buffer, 200 $\mu \mathrm{M}$ dNTPs, and $0.2 \mu \mathrm{M}$ of each primer under the following conditions: heating at $95^{\circ} \mathrm{C}$ for $3 \mathrm{~min}$, followed by 30 cycles of $94^{\circ} \mathrm{C}$ for $1 \mathrm{~min}, 55^{\circ} \mathrm{C}$ for $1 \mathrm{~min}$, and $72^{\circ} \mathrm{C}$ for $3 \mathrm{~min}$. After that, extension was carried out at $72^{\circ} \mathrm{C}$ for $10 \mathrm{~min}$. The PCR products were analyzed on $1.5 \%$ agalose gels and recovered from the gel using a Wizard ${ }^{\circledR}$ SV Gel and PCR Clean-Up System (Promega, Madison, USA). The recovered samples were cloned using the pGEM-T easy vector system I (Promega, Madison, USA).

A total of 48 clones were randomly selected and partially sequenced (about $500 \mathrm{bp}$ ). The accession numbers of the decided sequences were AB518229 to AB518276. These sequences were compared with the GenBank nucleotide database library by BLAST on-line searches (http://www.ncbi.nlm.nih.gov/ blast/blast.cgi). The sequences were then manually aligned with the sequences selected from the GenBank and the sequences obtained from the Ribosomal RNA Project II database (http://www. cme.msu.edu/RDP/html/index.html). Alignments of nucleotide sequences were performed using the CLUSTALW 1.83 program (Thompson et al., 1994). Phylogenetic analyses were completed using PHYLIP package version 3.5 (Felsensteinl, 1989). The distance matrix was calculated using the Kimura twoparameter model (Kimura, 1980), and phylogenetic trees were constructed based on the neighbor-joining (NJ) method (Saitou and Nei, 1987) (Fig.2).

As a result, 36 clones showed a high similarity to the $\alpha$-subdivision of the Proteobacteria. In this clade, 8 clones (YMII2 etc.), which had been incubated in YM medium at $25^{\circ} \mathrm{C}$, were related to the genus Agrobacterium. Two clones (LB amp1, etc.), which had been incubated in 100-fold diluted LB medium, showed a high similarity to the genus of 


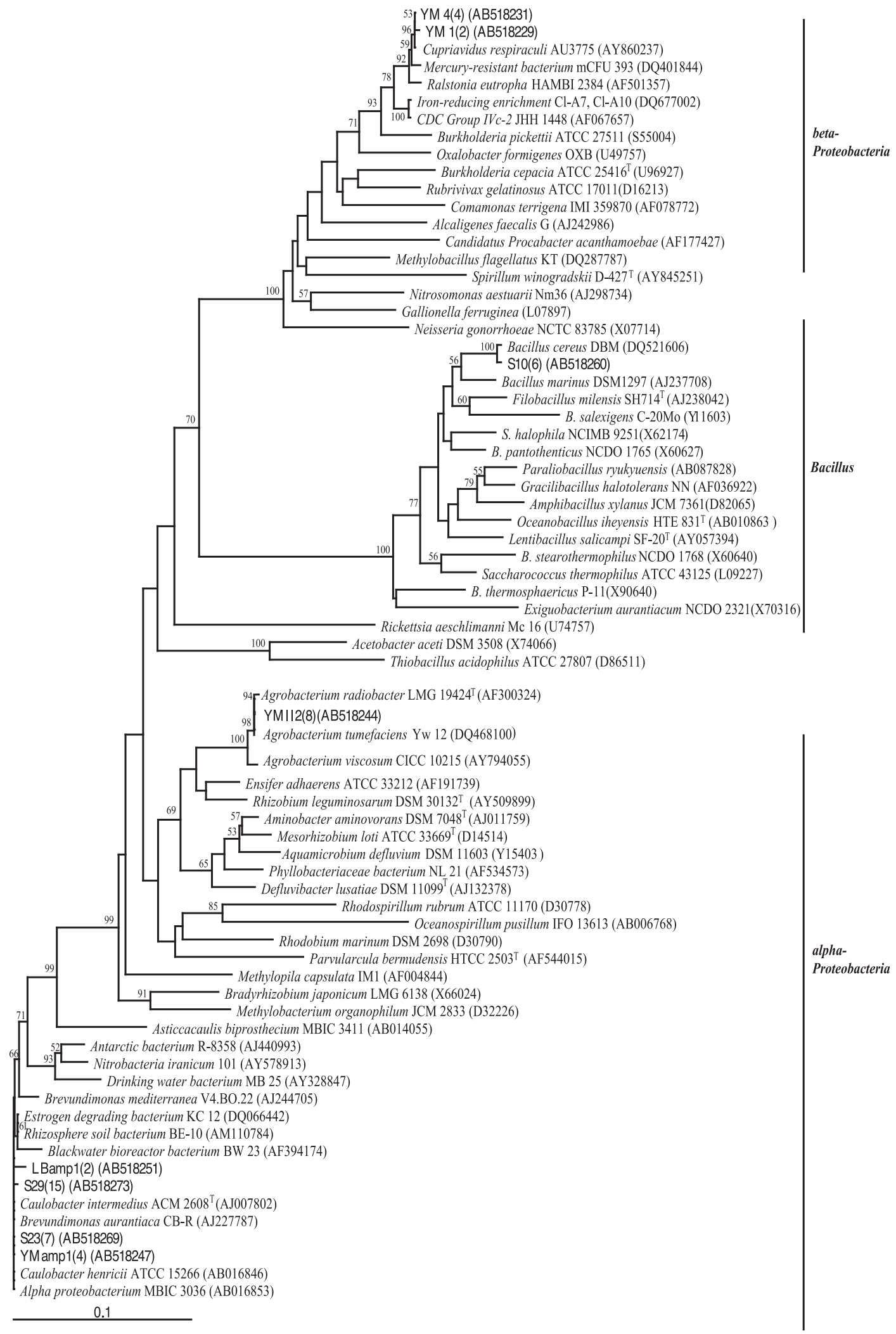

FIG. 2. Unrooted neighbor-joining phylogenetic tree of the bacteria group. Bold letters are clones from Jizo-lke. Clones are based on $16 \mathrm{~S}$ rDNA sequences (about $500 \mathrm{bp}$ ). Bootstrap values $>50 \%$ are shown at the nodes. The scale bar indicates 0.1 substitutions per nucleotide position. GenBank accession numbers are listed after each sequence name. The number in the parentheses shows the number of clones. 
Caulobacter, and 15 clones (clone name; S29, etc.), 7 clones (clone name; S23, etc.), and 4 clones (YM amp1, etc.), which had been incubated in YM medium, were related to the genus Brevundimonas.

A total of 6 clones (YM4, etc.), which had been incubated in YM medium, were grouped with the members of the $\beta$-subdivision of the Proteobacteria, with a specific affinity to the genus Cupriavidus. The remaining 6 clones ( $\$ 10$, etc.), which had been incubated in YM medium, exhibited high similarity to Bacillus of the phylum Firmicutes.

Recently, the phylogenetic diversity of bacteria has been studied based on culture collections from Antarctic sea-ice and pack ice (Margesin and Schinner, 1994; Bowman et al., 1997; Tindall, 2004). These culturing efforts have led to the discovery of new genera and species (Ellis-Evans, 1996; Bowman et al., 1997; Gosink et al., 1998). The species found were diverse, and within the divisions of the $\alpha$ - and $\gamma$-Proteobacteria, for example, Colwellia psychrotropica, the Cytophaga-FlavobacteriumBacteroides (CFB) group, class Proteobacteria, order Verrucomicrobiales, and the class Actinobacteria, Clostridium/Bacillus, a subphylum of gram-positives. Our study also showed the existence of the $\alpha$-and $\beta$-subdivision of the Proteobacteria and Bacillus in the Antarctic lake, and the bacteria were living and had the ability to grow. Wasano et al. (1999) indicated that Bacillus thuringiensis, which exists widely in several environments, was not observed in the coastal area near Syowa Station. However, our results clarified the presence of this universal genus and suggested that the bacteria in the Antarctic lake were not specific to this environment and that the species existed widely on a global scale.

Antarctica is one of the most undeveloped regions in the world and has been isolated for a long time. The distance is great from regions, in which a large number of organisms exist, and it has been believed that the exchange of organisms and anthropogenic influence have been minimal or nonexistent. However, the results of cultivation and phylogenetic analysis in this study indicated that the bacterial community in an Antarctic lake was not composed of species only adapted to the Antarctic environment. Some bacteria have the ability to grow at higher temperatures than those in the Antarctic, and species were not specific to Antarctica. Therefore, considering the increase of the movement of microorganisms accompanying the travel of people to and from Antarctica and other continents, some Antarctic bacteria might acquire new habitats on a global scale. Moreover, there is the danger that the organisms would be pathogens. Since Antarctica is an undeveloped region, the pathogens might be novel. Considering the recent pandemic by several novel pathogens such as the Ebola virus which originated from an undeveloped region, more research about the current state of organisms in Antarctica and the exchange of several organisms is important.

\section{REFERENCES}

Bowman, J. P., McCammon, S. A., Brown, M. V., Nichols, D. S., and McMeekin, T.A. (1997) Diversity and association of psychrophilic bacteria in Antarctic sea ice. Appl. Environ. Microbiol., 63, 3068-3078.

Bowman, J.P., McCammon, S. A., Rea, S. M., and McMeekin, T. A. (2000) The microbial composition of three limnologically disparate hypersaline Antarctic lakes. FEMS Microbiol. Lett., 183, 81-88.

Brambilla, E., Hippe, H., Hagelstein, A., Tindall, B. J., and Stackebrandt, E. (2001) 16S rDNA diversity of cultured and uncultured prokaryotes of a mat sample from lake fryxell, mcmurdo dry valleys, Antarctica. Extremophiles, 5, 23-33.

Ellis-Evans, J.C. (1996) Microbial diversity and function in Antarctic freshwater ecosystems. Biodivers. Conserv., 5, 1395-1431.

Felsensteinl, J. (1989) PHYLIP-phylogenetic inference package (version 3.2). Cladistics., 5, 164-166.

Gosink, J. J., Woese, C. R., and Staley, J. T. (1998) Polaribacter general nov., with three new species, $P$. irgensii, sp. nov., P. franzmannii sp. nov. \& P. filamentus, sp. nov., gas vacuolated polar marine bacteria of the Cytophaga / Flavobacterium /Bacteroides Group and reclassification of 'Flectobacillus glomeratus' as Polaribacter glomeratus. Int. J. Syst. Bacteriol., 48, 223235.

Kimura, M. (1980) A simple method for estimating evolutionary rates base substitutions through comparative studies of nucleotide sequences. J. Mol. Evol., 16, 111120.

Laybourn-Parry, J., and Marchant, H. J. (1992) The microbial plankton of freshwater lakes in the Vestfold Hills, Antarctica. Polar Biol., 12, 405-410.

Laybourn-Parry, J., James, M. R., McKnight, D. M., Priscu, M., Spaulding, S. A., and Shiel, R. (1997) The microbial plankton of lake Fryxell, southern Victoria Land, Antarctica during the summers of 1992 and 1994. Polar Biol., 17, 54-61.

Margesin, R., and Schinner, F. (1994) Properties of coldadapted microorganisms and their potential role in biotechnology. J. Biotechnol., 33, 1-14.

McEvoy GK, ed. (2006) AHFS Drug Information. Bethesda, MD: American Society of Health-System Pharmacists, Inc.

Ohta, H., and Hattori, T. (1983) Oligotrophic bacteria on organic debris and plant roots in a paddy field soil. Soil. Biol. Biochem., 15, 1-8.

Peng, Y., Walker, E. A., Davis, J. C., and Demain, A. L. (1999) A chemically-defined medium supporting growth and providing cells converting compactin to pravastatin. J. Ind. Microbiol. Biotechnol., 22, 78-79. 
Saitou, N., and Nei, M. (1987) The neighbor-joining method: a new method for reconstructing phylogenetic trees. Mol. Biol. Evol., 4, 406-425.

Sato, K. (1987) Effect of increasing pentachlorophenol (PCP) concentrations on bacterial populations in glycinepercolated soils. Biol. Fertil Soils., 5, 1-5.

Suwa, Y., and Hattori, T. (1984). Effects of nutrient concentration on the growth of soil bacteria. Soil. Sci. Plant. Nutr., 30, 397-403.

Thompson, J. D., Higgins, D. G., and Gibson, T. J. (1994)
Clustal W: improving the sensitivity of progressive multiple sequence alignment through sequence weighting, position-specific gap penalties and weight matrix choice. Nucleic Acids Res., 22, 4673-4680.

Tindall, B. J. (2004) Prokaryotic diversity in the Antarctic: the tip of the iceberg. FEMS Microbial Ecol., 47, 271-283.

Wasano, N., Imura, S., and. Ohba. (1999) Failure to recover Bacillus thuringiensis from the Lutzow-Holm Bay region of Antarctica. Lett. Appl. Microbiol., 28, 49-51. 